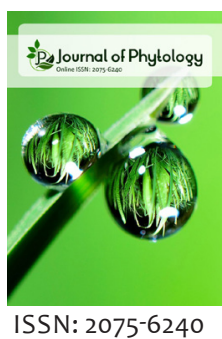

Received: March 17, 2021 Revised: April 19, 2021 Accepted: April 22, 2021 Published: May 13, 2021

* Corresponding author: Noorasmah Saupi,

E-mail: noorasmah@upm.edu.my KEYWORDS: Piper umbellatum L., indigenous leafy vegetable, nutrients, morphology

\section{Morphological characterization and nutrient assessment of wild pepper, Piper umbellatum L. (Piperaceae) grown in Sarawak, Malaysia}

\author{
Noorasmah Saupi',3*, Philip Lepun,3, Ribka Alan², Muta Harah Zakaria4, \\ Ainul Asyira Saidin', and Nurul Aisyah Yusli'
}

\begin{abstract}
${ }^{1}$ Faculty of Agriculture Science and Forestry, Universiti Putra Malaysia Bintulu Sarawak Campus, 97008 Bintulu, Sarawak, Malaysia, ${ }^{2}$ Faculty of Humanities, management and Science, Universiti Putra Malaysia Bintulu Sarawak Campus, 97008 Bintulu, Sarawak, Malaysia, ${ }^{3}$ nstitute of Ecoscience Borneo, Universiti Putra Malaysia Bintulu Sarawak Campus, 97008 Bintulu, Sarawak, Malaysia, ${ }^{4}$ Faculty of Agriculture, Universiti Putra Malaysia, 43400 Serdang, Selangor, Malaysia
\end{abstract}

\section{ABSTRACT}

Wild pepper, Piper umbellatum L. is traditionally consumed as a leafy vegetable by the indigenous Kenyah tribesmen of Belaga, Sarawak, Malaysia. The shoots are normally harvested from secondary forest floors. The present study was carried out to determine the morphological and nutritional characteristics of $P$. umbellatum, i.e., proximate, mineral, total phenolic content (TPC), total flavonoid content (TFC), vitamin C, and anti-nutrients, i.e., oxalate and phytate. The results showed that P. umbellatum possesses an ovate, alternate, entire and non-glandular trichome on its leaf surface. The inflorescence comprises an oblongoid spike attached to a peduncle and the ripened berries were orange and red in color The results also revealed that the leaves of P. umbellatum had a high moisture content (63.27\%), other recorded nutrient values were ash $(8.62 \%)$, crude fiber $(19.32 \%), \mathrm{K}(1280.20 \mathrm{mg} / \mathrm{l} 00 \mathrm{~g}), \mathrm{Ca}(570.60 \mathrm{mg} / \mathrm{l} 00 \mathrm{~g}), \mathrm{Mg}(323.80 \mathrm{mg} / 100 \mathrm{~g})$ and P $(291.14 \mathrm{mg} / 100 \mathrm{~g})$, TPC $(510.63 \mathrm{mg} / 100 \mathrm{~g})$, TFC $(377.82 \mathrm{mg} / 100 \mathrm{~g})$ and phytate $(411.67 \mathrm{mg} / 100 \mathrm{~g})$. Thus the consumption of the P. umbellatum as a leafy vegetable supplies a good dose of various essential nutrients.

\section{INTRODUCTION}

The Piperaceae family is widely distributed in tropical regions and comprises over 1000 species (Parthasarathy et al., 2006). Piper umbellatum L. (syn. Pothomorphe umbellata (L.) Miq., Lepianthes umbellata (L.) Raf., Heckeria umbellata (L.) Kunth and Peperomia umbellata (L.) Kunth) is a species which grows extensively in Malaysian rainforests. This species is also known by several common names such as umbelled pepper, cowfoot, Segumbar urat (Peninsular Malaysia), Lemba (Moluccas), Capeba or pariparoba (Brazil), Bumbu, Domboo, Tombo and Ucheng-ucheng (Java) (Tawan et al., 2002; Mensah et al., 2013; da Silva et al., 2014). The importance of P. umbellatum as a medicinal plant has been described in various studies. The extract from its leaves and other parts of the plant have been used for the treatment of infectious and inflammatory diseases (Roersch, 2010), snake venom (Núñez et al., 2005) and as an anti-cancer remedy (Iwamoto et al., 2015). The plants also been used by witchdoctors in Cameroon (Agbor et al., 2005; Roersch et al., 2010), as a fragrance in Ecuador (Pohle \& Reinhardt, 2004; Roersch et al., 2010), and as fish bait in Ghana (Roersch et al., 2010).

In many countries, the leaves of $P$. umbellatum is consumed as a leafy vegetable and condiment as was reported by Mensah et al. (2008). In Malaysia, P. umbellatum is also used as a leafy vegetable by locals especially by the Kenyah ethnic group residing in Sungai Asap, Belaga, Sarawak. The plant can occasionally be found growing on the forest floor within the Belaga area. It is a perennial or woody herb that commonly grows up to $1.0-2.5 \mathrm{~m}$ tall (Roersch, 2010). It flourishes in shady, moist habitats with moderate light penetrating through the forest gaps. The local people collect this plant from the nearby forests along their longhouses and sell it at the nearest market. The leaves are prepared as one of the ingredients for freshwater fish soup dishes and are also eaten as a relish together with their staple diet. The 
locals believe that the plant contain high nutritional values which are good for health. However, previous studies conducted have mainly focused on the medicinal uses of this plant rather than its nutritional attributes. Additionally, there is far less scientific data available on morphological descriptions and agronomic requirements of this species. Therefore, the present study was conducted for the purpose of describing the morphology of $P$. umbellatum as well as its nutrient and anti-nutrient contents.

\section{MATERIALS AND METHODS}

\section{Sample Collection}

The samples of P. umbellatum were collected at Sg. Asap secondary forest, Belaga, Sarawak. The selected samples were then placed in an ice chest for transportation to the Agronomy Laboratory, Universiti Putra Malaysia Kampus Bintulu, Sarawak.

\section{Morphological Study}

In the laboratory, the morphological characteristics of P. umbellatum at leaf, inflorescence and berry parts were observed and measured. The study involved the assessment of the qualitative and quantitative traits of the plant as described in Table 1. The qualitative traits were measured at the study site using a metric ruler and vernier caliper. Whereas micro measurements such as trichome length on leaf surface was observed under Keyence Digital Microscope VHX-600.

Table 1. The qualitative and quantitative measurements of P. umbellatum.

\begin{tabular}{lll}
\hline Plant Parts & Qualitative parameter & Quantitative parameter \\
\hline Leaf & Shape, arrangement, & Leaf dimension and \\
& trichome & trichome lengths \\
Inflorescence & Spike color, peduncle & Spike and peducle \\
& color & dimensions \\
Berry & Berry shape, berry and & Berry diameter and \\
& pedicle color & pedicle dimensions \\
\hline
\end{tabular}

\section{Nutrient and Anti-nutrient Contents}

\section{Sample preparation}

The samples of P. umbellatum were collected after measurements of qualitative traits were taken. The samples were then placed in the ice chest for transportation to the Agronomy Laboratory, Universiti Putra Malaysia Bintulu Sarawak Campus. In the laboratory, the edible parts of the samples comprising the leaves and petiole were then separated and selected for nutrient analysis. The leaves of $P$. umbellatum were washed under running tap water to remove any dirt and contaminant and were then subsequently rinsed with distilled water. The moist leaves were left to evaporate at room temperature. The leaves then were then oven dried in $60^{\circ} \mathrm{C}$ for 24 hours following the methods of Abuye et al. (2003) and ground into a dried powdered sample using a heavy duty blender. The powdered sample was stored in airtight containers until further analysis.

\section{Proximate composition}

The moisture, ash, crude protein, crude fiber, crude fat, total carbohydrate and energy of $P$. umbellatum leaves were determined in triplicate according to the Association of Official Analytical Chemists (AOAC, 1990) methods. The percentage of crude protein content was estimated by multiplying of nitrogen content by a 6.25 factor $(978.04$, AOAC, 1990). The crude fiber content was extracted with $1.25 \%$ sulphuric acid $\left(\mathrm{H}_{2} \mathrm{SO}_{4}\right)$ and $1.25 \%$ sodium hydroxide $(\mathrm{NaOH})$ and then quantified using the 2010 Fibertec System Foss Tecator, Sweden (930.10, AOAC, 1990). The crude fat content was extracted using a 2055 Soxtec Avanti Manual System, Sweden according to method 930.09 (AOAC, 1990). The carbohydrate content was determined through difference of $100 \%$ DW sample with the total of crude protein, crude fiber and ash (AOAC, 1990).

\section{Mineral content}

The ash obtained from the ash content analysis was used for mineral digestion. A few drops of distilled water were added into porcelain crucibles followed by $2 \mathrm{~mL}$ of concentrated hydrochloric acid ( $\mathrm{HCl})$. Next, $10 \mathrm{~mL}$ of $20 \% \mathrm{HNO}_{3}$ was added and the samples was left to evaporate on a hotplate. The sample was then filtered using Whatman filter paper No. 2 into $100 \mathrm{~mL}$ volumetric flasks (method 922.02, AOAC, 1990). The concentration of $\mathrm{K}, \mathrm{Ca}, \mathrm{Mg}, \mathrm{Na}, \mathrm{Fe}, \mathrm{Zn}, \mathrm{Cu}$ and Mn were determined through the use of an Atomic Absorption Spectrophotometer (AA800 Perkin-Elmer, Germany) whereas $\mathrm{P}$ content was measured using the blue development method according to Murphy and Riley (1992) and quantified using a UV-Vis Spectrophotometer (Lambda 25 Perkin-Elmer, Germany).

\section{Antioxidant content}

TPC content was determined using the Folin Ciocalteu's method by Singleton et al. (1999). $1 \mathrm{~g}$ of the oven dried grounded samples was weighed and soaked in $10 \mathrm{~mL}$ of methanol $70 \%(\mathrm{w} / \mathrm{v})$ and centrifuged at $1000 \mathrm{rpm}$ for 10 minutes. $1 \mathrm{~mL}$ of the aliquots were pipetted into individual test tubes. Standard gallic acid in concentrations of 10, 20, 40, 60, 80 and $100 \mu \mathrm{g} / \mathrm{mL}$ was used as standards and $0.5 \mathrm{~mL}$ of Folin Ciocalteu's reagent was added. The tubes were incubated for 2 hours at room temperature for color development. The absorbance was measured at $750 \mathrm{~nm}$ by using a UV-VIS Spectrophotometer (Lambda 25 Perkin Elmer, Germany). The TPC content in the samples calculated by equation from the calibration curve and expressed in gallic acid equivalent (mg GAE/ $100 \mathrm{~g}$ ) of dry mass.

The TFC content was determined using the method described by Kamtekar et al. (2014). $1 \mathrm{~mL}$ of the aliquots and $1 \mathrm{~mL}$ of blank as well as standard quercetin at $0.1,0.2,0.4,0.6,0.8$ and $1.0 \mathrm{mg} / \mathrm{mL}$ were placed into the test tubes followed by the addition of $4 \mathrm{~mL}$ of distilled water and $0.3 \mathrm{~mL}$ of $5 \%$ sodium nitrite solution. The mixture was left to rest for 5 minutes before $0.3 \mathrm{~mL}$ of aluminium chloride solution was added. This mixture was allowed to stand for 6 minutes. Finally, $2 \mathrm{~mL}$ of $1 \mathrm{M}$ sodium hydroxide was added and distilled water was added to 
make up the volume of $10 \mathrm{ml}$. The resultant mixture was mixed thoroughly until a yellowish orange color developed. The TFC content was measured at $510 \mathrm{~nm}$ of absorbance using a UV-VIS Spectrophotometer (Lambda 25 Perkin Elmer, Germany). The TFC was expressed as mg of quercetin equivalents per $100 \mathrm{~g}$ quercetin equivalents $(\mathrm{mg} \mathrm{QE} / \mathrm{l} 00 \mathrm{~g}$ ) on a dry mass basis.

Vitamin $\mathrm{C}$ content was determined by extracting $3 \mathrm{~g}$ of the ground samples using $3 \mathrm{~mL}$ of $10 \%$ metaphosphoric acid which was diluted using deionized water up to the volume of a $50 \mathrm{~mL}$ volumetric flask. The $\mathrm{pH}$ of the filtrate was adjusted to 5.0-5.25 using $4 \mathrm{M} \mathrm{NaOH}$ or $10 \%$ metaphosphoric acid and then $10 \mathrm{mg}$ dithiothreitol was added. The mixture was incubated in the dark at room temperature for 1 hour. The mixture was then filtered and re-filtered through a $0.45 \mu \mathrm{m}$ membrane filter prior to injection for HPLC analysis. Vitamin C determination was performed using an HPLC system using a Zorbax $5 \mu \mathrm{m}$ ODS column $(250 \times 4.6 \mathrm{~mm})$ with an analytical guard column $\mathrm{C}-130 \mathrm{~B}(2 \times 20 \mathrm{~mm})$. The mobile phase was $0.5 \% \mathrm{KH}_{2} \mathrm{PO}_{4}$ at a flow rate of $0.8 \mathrm{~mL} / \mathrm{min}$. Vitamin C was monitored at $245 \mathrm{~nm}$. The results were expressed as $\mathrm{mg}$ of ascorbic acid per $100 \mathrm{~g}$ fresh weight (mgAA/l00 g).

\section{Antinutrient contents}

The oxalate content was determined by the methods described by Day and Underwood (1986). Approximately $1 \mathrm{~g}$ of the ovendried grounded sample was weighed and placed in a $100 \mathrm{~mL}$ conical flask. Next, $75 \mathrm{~mL}$ of $3 \mathrm{M} \mathrm{H} 2 \mathrm{SO} 4$ was added into the conical flask and stirred using a magnetic stirrer for one hour. The mixture was then filtered into a plastic vial and $25 \mathrm{~mL}$ of the collected filtrate was taken. The filtrate was titrated while hot against $0.05 \mathrm{M}$ of potassium permanganate (KMnO4) until the mixture turned a persistent faint pink color (for at least 30 seconds). The volume of the $\mathrm{KMnO} 4$ titrated was recorded and calculated using the assumption that $1 \mathrm{~mL}$ of $\mathrm{KMnO} 4$ is equivalent to $2.2 \mathrm{mg}$ oxalate.

Phytic acid was determined using the procedures of Lucas and Markakas (1975). About $2 \mathrm{~g}$ of the oven-dried grounded samples was weighed and put into a $250 \mathrm{~mL}$ conical flask. Next, 100 $\mathrm{mL}$ of $2 \%$ concentrated $\mathrm{HCl}$ was poured into the conical flask and left for three hours. The mixture was filtered using the Whatman filter paper No. 2 and $50 \mathrm{~mL}$ of the collected filtrate was moved to $250 \mathrm{~mL}$ beakers. Then, $107 \mathrm{~mL}$ of distilled water was added into each of the beakers followed by $10 \mathrm{~mL}$ of $0.3 \%$ ammonium thiocyanate solution as an indicator. The titration was carried out against the standard iron chloride solution which contained $0.00195 \mathrm{~g}$ iron per $\mathrm{mL}$. The titration volume was recorded and used to calculate the phytic acid content using the formula: \% Phytic acid $=($ titre value $\times 0.00195) \times 1.19 \times 100$.

\section{Statistical Analysis}

The quantitative morphological characteristics of P. umbellatum and its nutritional content were analyzed using a one way analysis of variance (ANOVA) at $\mathrm{p} \leq 0.05$ using the Statistical Software Program, SAS Version 9.4.

\section{RESULTS AND DISCUSSION}

\section{Morphological Characteristics}

The leaves of Piper umbellatum grown in Malaysia are of ovate shape for the entire margin. The leaves form an alternate pattern between each other on the plant. The adaxial and abaxial surface has a non-glandular trichome also at the petiole (Figure 1 and Figure 2). It has big leaves with the mean dimension at 25.71

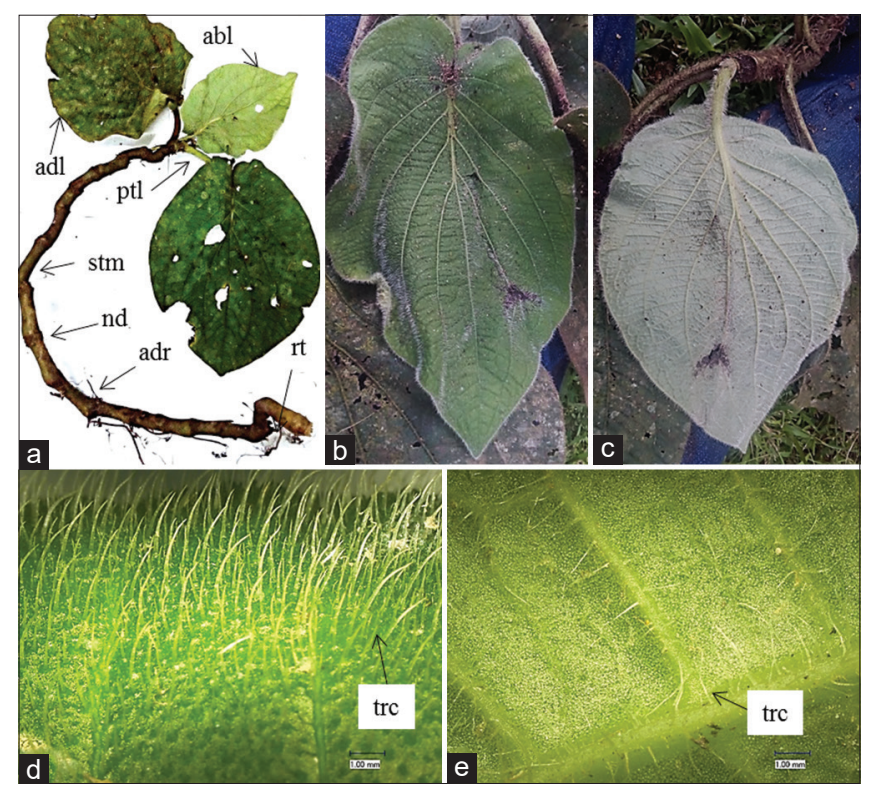

Figure 1: Vegetative parts of $P$. umbellatum (a) Woody shrub of $P$. umbellatum showing adaxial or upper leaf (adl), abaxial or lower leaf (abl), petiole ( $\mathrm{ptl})$, stem (stm), node (nd), adventitious root (adr) and root (rt), (b) leaf adaxial surface, (c) leaf abaxial surface, (d) microscopic image showing the presence of trichome (trc) on adaxial surface, and (e) microscopic image showing the presence of trichome (trc) on abaxial surface.

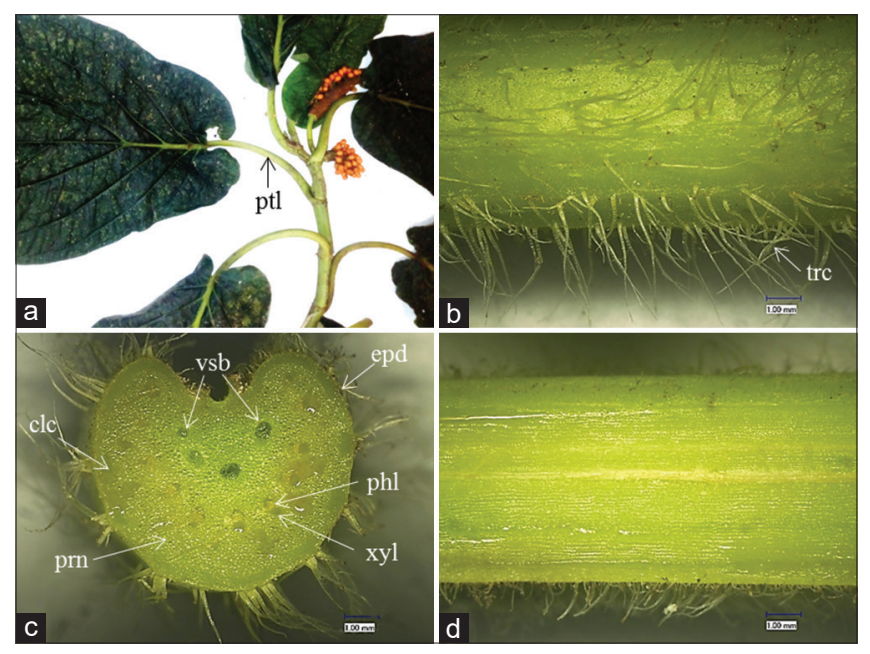

Figure 2: Vegetative parts of $P$. umbellatum: Petiole (a) P.umbellatum showing petiole (ptl), (b) abundance of non-grandular trichomes on the petiole, (c) cross section of the petiole consists of epidermis (epd), collenchyma (clc), parenchyma (prn), phloem (phl), xylem (xyl) and vascular bundles (vsb), and (d) longitudinal section of the petiole. 
x $2.24 \mathrm{~cm}$ whereas the mean of the trichome length averages $1.58 \mathrm{~mm}$ (Table 2). The leaves possessed similar characteristics to those grown in the Dominican Republic (Roersch, 2010). The trichome growth exhibited various functional adaptations for environmental stress, increased water retention capability and mechanical defense against herbivores (Medeiros \& Boligon, 2007; Kenzo et al., 2008).

The inflorescence is axillary or leaf opposed spikes, the orientation is erect and usually in false umbels with the pedicels bearing the bracts (Figure 3). The inflorescence consists of an oblongoid spike which is creamy white to yellowish orange in color. The spike measures approximately 6.21 x $0.12 \mathrm{~cm}$ (length $\mathrm{x}$ width). It is attached to a light green color peduncle which develops to about $3.19 \times 0.52 \mathrm{~cm}$ (length $\mathrm{x}$ width). The peduncle and spike length measured in the current study was within the range of those reported in other studies (Roersch et al., 2010). Flowering occurs throughout the year, depending on water availability (Nwauzoma et al., 2013).

The berry of $P$. umbellatum is a fleshy drupe or berry form, which is $4.22 \mathrm{~mm}$ in mean diameter (Figure 4). The berry attaches to a light green color pedicel which measures $0.69 \times 0.10 \mathrm{~cm}$ (length $\mathrm{x}$ width). The characteristics are similar to those described in a study of $P$. umbellatum from Nigeria. The berry is commonly used for propagation and the color observed was a bright orange and red color. The striking color is to enable the plant to attract the attention of fruit-eating mammals as well as avians

Table 2. Quantitative and quantitative characteristics of P. umbellatum

\begin{tabular}{|c|c|c|}
\hline \multirow{2}{*}{$\frac{\text { Plant part }}{\text { Leaf }}$} & \multicolumn{2}{|c|}{ Qualitative traits } \\
\hline & Shape & Ovate \\
\hline & Arrangement & Alternate \\
\hline & Margin & Entire \\
\hline & Trichome type & Non-grandular \\
\hline \multirow[t]{3}{*}{ Inflorescence } & Spike shape & Oblongoid \\
\hline & Spike color & Yellowish orange \\
\hline & Peduncle color & Light green \\
\hline \multirow[t]{3}{*}{ Berry } & Berry shape & Drupe \\
\hline & Berry color & Orange and red \\
\hline & Pedicle color & Light green \\
\hline \multicolumn{3}{|c|}{ Quantitative traits } \\
\hline \multirow[t]{3}{*}{ Stem } & Stem diameter $(\mathrm{mm})$ & $21.73 \pm 2.98$ \\
\hline & Internode lenth (cm) & $5.53 \pm 0.34$ \\
\hline & Plant height $(\mathrm{cm})$ & $53.47 \pm 21.35$ \\
\hline \multirow[t]{5}{*}{ Leaf } & Blade length $(\mathrm{cm})$ & $25.71 \pm 1.70$ \\
\hline & Blade width $(\mathrm{cm})$ & $22.24 \pm 0.14$ \\
\hline & Petiole length (cm) & $14.87 \pm 1.24$ \\
\hline & Petiole diameter (mm) & $8.83 \pm 0.57$ \\
\hline & Trichome length (mm) & $1.58 \pm 0.03$ \\
\hline \multirow[t]{5}{*}{ Inflorescence } & Number of spike per plant & $3.00 \pm 1.53$ \\
\hline & Spike length (cm) & $6.21 \pm 0.76$ \\
\hline & Spike width $(\mathrm{cm})$ & $1.02 \pm 0.13$ \\
\hline & Peduncle length $(\mathrm{cm})$ & $3.19 \pm 0.54$ \\
\hline & Peduncle diameter $(\mathrm{cm})$ & $0.52 \pm 0.07$ \\
\hline \multirow[t]{4}{*}{ Berry } & Number of berries per spike & $85.75 \pm 19.45$ \\
\hline & Berry diameter (mm) & $4.22 \pm 0.12$ \\
\hline & Pedicel length (cm) & $0.69 \pm 0.03$ \\
\hline & Pedicel width $(\mathrm{cm})$ & $0.10 \pm 0.03$ \\
\hline
\end{tabular}

Data of quantitative traits were presented as mean \pm standard error of 9 samples
(Nwauzoma et al., 2013). However, the berry of P. umbellatum found in Nigeria was reported to be of a light brownish color.

\section{Nutrient and Anti-nutrient Contents}

\section{Proximate composition}

The results for the proximate composition of $P$. umbellatum showed that the moisture content of the edible parts was relatively high in comparison to ash, crude protein, crude fiber, crude fat and the total carbohydrate content (Table 3). The trend of the proximate analysis recorded in the study was observed in the following order: Moisture $>$ carbohydrate $>$

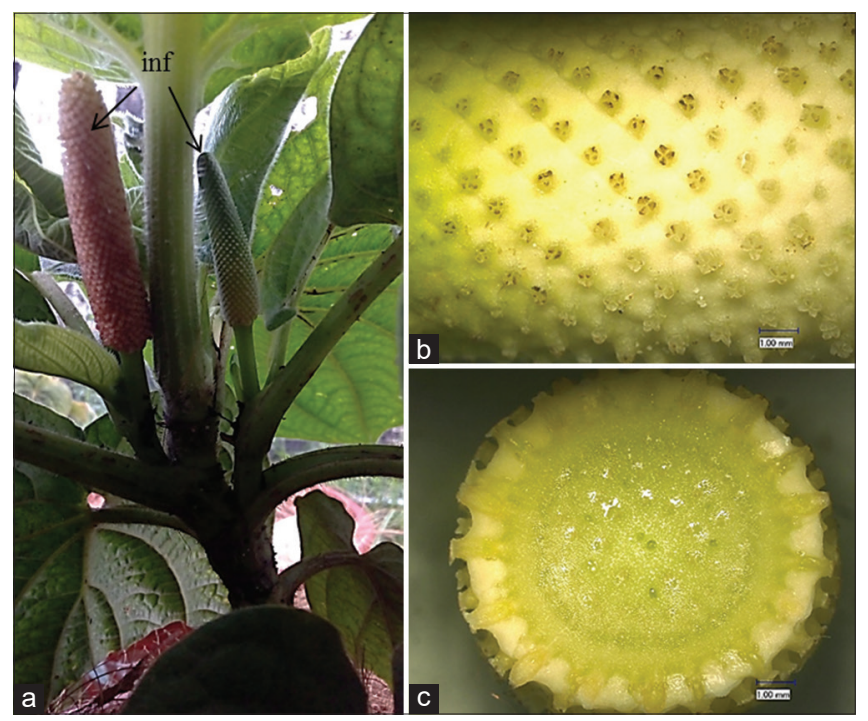

Figure 3: Reproductive parts of $P$. umbellatum: Inflorescence (a) Woody shrub of $P$. umbellatum showing inflorescence (inf), (b) flower spike showing individual, perianthless flowers with bracts, and (c) cross section of the spike.

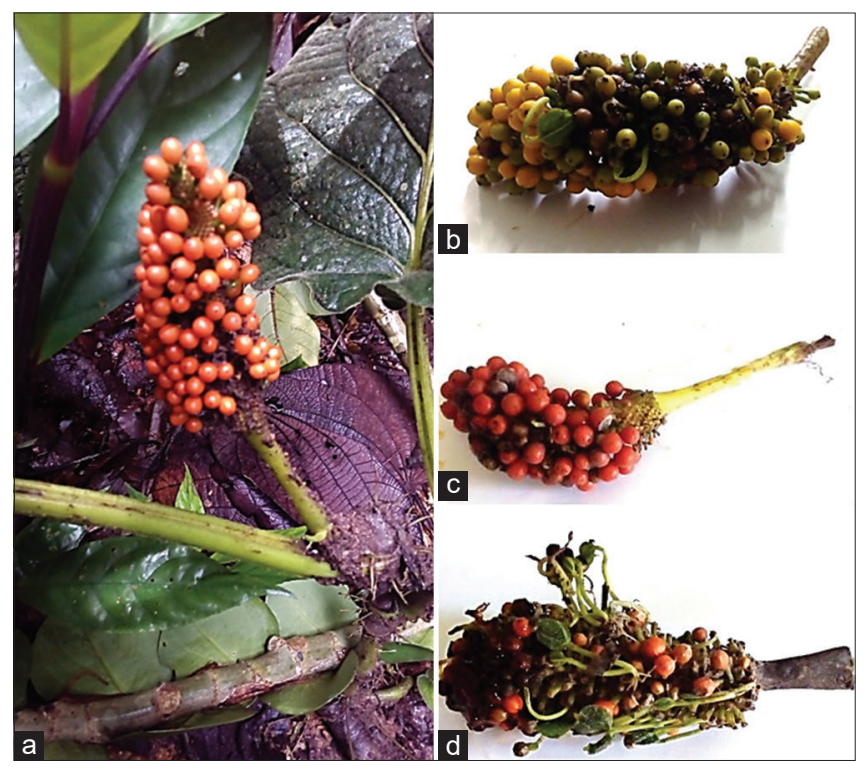

Figure 4: Reproductive parts of $P$. umbellatum: Fruits (a) Orange berries, (b) yellow berries, (c) red berries, and (d) shoots beginning to grow from ripened berries. 
crude fiber $>$ ash $>$ crude protein $>$ crude fat. However, the proximate analysis performed only for the edible parts of the plant.

The moisture content of the fresh weight sample was found to be $63.27 \%$ and comparable with other selected Malaysian leafy vegetables as reported by Hoe and Siong (1999). However, the result obtained in the current study was approximately one times lower than P. umbellatum recorded by Mensah et al. (2013) in Nigeria. This may be influenced by several factors such as sample maturity and agro-climatic conditions (Gupta et al., 2005). In addition, agro-ecological areas in Nigeria are heavily influenced by the airmass originating from the South Atlantic Ocean which increase the humidity in the country especially during the rainy season (Eludoyin \& Adelekan, 2012). Due to the presence of high moisture content, appropriate handling and processing methods are necessary to increase the shelf life of P. umbellatum and reduce the rate of deterioration (Ooi et al., 2012).

Ash content is used to indicate the presence of mineral nutrients in a plant sample. The ash content recorded in the present study was $8.62 \%$ which is similar to other leafy vegetables such as Basella alba (8.23\%) and Morus alba (8.91\%) as found in prior studies done by Saha et al. (2015) and Iqbal et al. (2012) respectively. However, this value was found to be approximately three times lower than Peperomia pellucida (31.2\%) which is consumed in Malaysia (Ooi et al., 2012). The high ash percentage found in the P. umbellatum indicates a high mineral nutrient content.

The crude protein obtained during the current study was found to be $1.14 \%$ which is lower in comparison to other studies. Crude protein in P. umbellatum as recorded by Mensah et al. (2013) was 3.9\%, which is roughly three times higher than the readings from the current study. A comparison with P. pellucida also showed that the vegetable had nine times the amount of protein as opposed to P. umbellatum (Ooi et al., 2012). This indicates that $P$. umbellatum is not a complete source of dietary protein, hence its consumption with other protein rich sources such as meats is highly recommended.

However, in terms of crude fiber the results obtained from this study showed P. umbellatum to have a high content composition of $19.32 \%$. This value was similar with those obtained from a previous study carried out by Mensah et al. (2013) who found a value of $20.20 \%$ for crude fiber. The results

Table 3. The nutrient and antinutrient composition of P. umbellatum.

\begin{tabular}{lc}
\hline Proximate & Concentration (\%) \\
\hline Moisture* & $63.27 \pm 0.78$ \\
Ash & $8.62 \pm 0.11$ \\
Crude protein & $1.14 \pm 0.07$ \\
Crude fiber & $19.32 \pm 0.75$ \\
Crude fat & $0.86 \pm 0.05$ \\
Total carbohydrate & $33.33 \pm 1.37$ \\
\hline
\end{tabular}

Data represented in means \pm standard error (SE) of dry weight. Values noted with asterisk $\left(^{*}\right)$ are represented as fresh weight showed that P. umbellatum is a good source of dietary fiber. Fiber is considered an important nutrient for health due to its potential to reduce the occurrence of colon disease, cancer, diabetes, heart disease and also to help improve digestion (Alam et al., 2016).

The crude fat content obtained from the current study was only $0.86 \%$, it was the lowest percentage out of all the other compositions. The result fell within the range of various leafy vegetables consumed in India (0.19-4.19\%) (Saha et al., 2015). This showed that P. umbellatum is a low fat food and thus its consumption may prove beneficial to reduce the incidence of obesity and cardiovascular diseases (Dewell \& Ornish, 2007). Thus the consumption of P. umbellatum can be recommended as part of a dietary plan for reducing body weight.

The total carbohydrate content obtained in this study was $33.33 \%$ which was comparable to the results of prior studies regarding P. umbellatum (38.00\%) and P. pellucida (46.58\%) (Ooi et al., 2012; Mensah et al., 2013). The high carbohydrate content enables the plant to supply a significant amount of useful energy for one to carry out their daily activities (Yisa et al., 2010; Saha et al., 2015).

\section{Mineral Content}

The $\mathrm{K}$ content recorded in the study was the highest in comparison to other elements. The trend of the mineral elements observed in this study was in the following order: $\mathrm{K}$ $>\mathrm{Ca}>\mathrm{Mg}>\mathrm{P}>\mathrm{Fe}>\mathrm{Mn}>\mathrm{Na}>\mathrm{Zn}>\mathrm{Cu}$. P. umbellatum contains a significantly high $\mathrm{K}$ content with a concentration of $1280.20 \mathrm{mg} / 100 \mathrm{~g}$ (Table 4). The values recorded were relatively low when compared to other Malaysian leafy vegetables such as P. pellucida $(6977.00 \mathrm{mg} / 100 \mathrm{~g})$ and Limnoscharis flava (4202.50 mg/l00 g) (Saupi et al., 2009; Ooi et al., 2012). However, the values were comparable to other leafy vegetables such as Pangium edule (1157.25 mg/l00g) and Gnetum gnemon (Ainul Asyira et al., 2016). The K content in P. umbellatum contributes approximately $36.58 \%$ of the 3500 $\mathrm{mg} / \mathrm{d}$ Recommended Dietary Allowance (RDA) (WHO, 2012). A high intake of $\mathrm{K}$ in a daily diet could potentially reduce the risks of coronary heart disease as well as other chronic diseases (Weaver, 2013; Ainul Asyira et al., 2016). Potassium is a significant mineral for plants as it helps to govern enzyme activity, protein synthesis, stomatal activity, photosynthesis, in

Table 4. The mineral content in P. umbellatum.

\begin{tabular}{lc}
\hline Mineral & Concentration $(\mathrm{mg} / 100 \mathrm{~g})$ \\
\hline $\mathrm{K}$ & $1280.20 \pm 120.69$ \\
$\mathrm{P}$ & $291.14 \pm 21.30$ \\
$\mathrm{Ca}$ & $570.60 \pm 21.57$ \\
$\mathrm{Mg}$ & $323.80 \pm 18.31$ \\
$\mathrm{Na}$ & $4.00 \pm 1.05$ \\
$\mathrm{Fe}$ & $16.34 \pm 0.95$ \\
$\mathrm{Zn}$ & $3.16 \pm 0.22$ \\
$\mathrm{Cu}$ & $2.18 \pm 0.26$ \\
$\mathrm{Mn}$ & $12.10 \pm 0.62$ \\
$\mathrm{Na} / \mathrm{K}$ & $0.01 \pm 0.00$ \\
$\mathrm{Ca} / \mathrm{P}$ & $2.00 \pm 0.14$ \\
\hline
\end{tabular}

Data represented in means \pm standard error (SE) of the dry weight 
addition to increasing crop production (Prajapati \& Modi, 2012; Wang et al., 2013).

The concentration of $\mathrm{P}$ in the P. umbellatum was estimated to be approximately $291.14 \mathrm{mg} / 100 \mathrm{~g}$. The amount is comparable to Justicia flava $(292.00 \mathrm{mg} / \mathrm{l00g})$ and Emex australis $(290.00 \mathrm{mg} / 100 \mathrm{~g})$, which are common leafy vegetables consumed in South Africa (Odhav et al., 2007). The consumption of 100 grams of P. umbellatum can provide $41.59 \%$ of the RDA which is recommended to be $700 \mathrm{mg} / \mathrm{d}$ for adults, lactating and pregnant women (Sawka, 2005). Phosphorus is required for the body to carry out cellular metabolism and skeletal mineralization and its deficiency may cause osteoporosis especially in women (Heaney, 2004). According to Karp et al. (2007), phosphorus is not a limiting nutrient as it is readily available in various vegetables and plant-based foods, however a high percentage of $\mathrm{P}$ which is present in plant based foods are bonded with phytate making it unavailable for body absorption.

High concentrations of Ca was also observed in the P. umbellatum at $570.60 \mathrm{mg} / 100 \mathrm{~g}$, these results were similar to those reported by Ooi et al. (2012) and Saupi et al. (2009) in other leafy vegetables. The Ca obtained in the study can contribute $43.89 \%$ of the $1300 \mathrm{mg} / \mathrm{d}$ RDA. P. umbellatum has good potential as a source of dietary $\mathrm{Ca}$ and its intake may contribute to bone and teeth health, nerve regulation and muscle function ( $\mathrm{Ng}$ et al. 2012). Ca deficiency may lead to rickets in children and osteomalacia in adults (Soetan et al., 2009; Ainul Asyira et al., 2016).

The Mg content recorded in the present study was found to be $323.80 \mathrm{mg} / 100 \mathrm{~g}$ which is comparable to L. flava $(228.10 \mathrm{mg} / 100 \mathrm{~g})$ which is commonly consumed by Malaysians (Saupi et al., 2009). Magnesium is required in appropriate amounts to carry out many of the bodily functions such as glucose metabolism and insulin homeostasis (Song et al., 2004; Barbagalo et al., 2003). The consumption of $P$. umbellatum in one serving of $100 \mathrm{~g}$ is estimated to contribute about $77.10 \%$ of the $420 \mathrm{mg} / \mathrm{d}$ of the RDA for Magnesium (Otten et al., 2006). Mg deficiency was reported to cause Type 2 diabetes mellitus (He et al., 2006).

P. umbellatum was found to have a low content of $\mathrm{Na}$ with a concentration of just $4.00 \mathrm{mg} / 100 \mathrm{~g}$. This result was comparable to the $\mathrm{Na}$ content of Erechtites hieracifolia $(5.30 \mathrm{mg} / \mathrm{l} 00 \mathrm{~g}$ ), a wild leafy vegetable commonly consumed in Indonesia (Srianta et al., 2012). However, this amount is 16 times lower than G. gnemon (65.00 mg/l00g) (Rukayah, 2002). This shows that $P$. umbellatum contain low concentrations of $\mathrm{Na}$, which is concurrent with various other studies showing that some varieties of leafy vegetables contain low amounts of $\mathrm{Na}$ (Gupta et al., 2005; Saha et al., 2015). The RDA for $\mathrm{Na}$ is recommended at $2300 \mathrm{mg} / \mathrm{d}$ for adults. From the results obtained P. umbellatum can contribute $0.17 \%$ of the required RDA for $\mathrm{Na}$ from a $100 \mathrm{~g}$ serving. The addition of salt during the preparation of dishes can also increase the amount of $\mathrm{Na}$ consumed. The overconsumption of $\mathrm{Na}$ may cause high blood pressure, cardiovascular diseases and stroke (WHO, 2012).

The iron content of P. umbellatum was found to be approximately $16.34 \mathrm{mg} / 100 \mathrm{~g}$ which is about seven times lower than P. pellucida
(119.30 mg/100g) (Ooi et al., 2012). Whereas, these values were comparable to that of Vernonia amygdalina $(16.43 \mathrm{mg} / 100 \mathrm{~g})$ as found by Gupta et al et al., (2012). The RDA of Fe for adults was between the ranges of 8-18 mg/day, hence the Fe content of P. umbellatum was found to be within this range (Sawka, 2005). This constitutes about $90.78 \%$ of the RDA for Fe. Iron is a major component of haemoglobin, proteins, enzymes and myoglobin (Sawka, 2005). Therefore, a deficiency of this mineral can lead to health problems such as astherosclerosis, autoimmunity disease, Parkinson's disease, fibrosis as well as other related diseases (Brewer, 2007).

The zinc content in P. umbellatum was relatively low with a concentration of $3.16 \mathrm{mg} / 100 \mathrm{~g}$. The values recorded were comparable to L. flava $(0.66 \mathrm{mg} / \mathrm{l00g})$ and this can contribute about $28.72 \%$ and $39.50 \%$ of the RDA in one $100 \mathrm{~g}$ of serving for adult males and females respectively. In general, $\mathrm{Zn}$ is required for many bodily functions and metabolic activities such as cell and protein division. A deficiency of Zinc causes anemia and retardation of fetal brain cells in pregnant women, although such deficiency rarely occurs (Chasapis et al., 2012). Copper is a micro element which was detected in low concentrations in P. umbellatum during the current study. P. umbellatum was found to contain $2.18 \mathrm{mg} / 100 \mathrm{~g}$ of $\mathrm{Cu}$ this was the lowest value recorded in comparison to the other elements detected. The $\mathrm{Cu}$ contain in the P. umbellatum is roughly two times higher than the RDA which recommends an intake of $0.9 \mathrm{mg} / \mathrm{d}$ (Sawka, 2005). Nonetheless, the consumption of P. umbellatum although exceeding the RDA for $\mathrm{Cu}$ is not regarded as harmful or toxic as the content was still lower than $10 \mathrm{mg} / \mathrm{d}$ of the Tolerable Upper Intake Level (UL). Cu deficiency in the general population is rarely reported (Sawka, 2005).

P. umbellatum was recorded to contain $12.10 \mathrm{mg} / 100 \mathrm{~g}$ concentrations of Mn. This amount was three time lower in comparison to the content of Moringa oleifera leaves $(43.27 \mathrm{mg} / 100 \mathrm{~g})$ (Saha et al., 2015). The findings suggest that P. umbellatum has a low Mn content in comparison to other vegetables. Manganese is required by the body to regulate and bind various enzymes in the body such as arginase, superoxide dismutase and pyruvate carboxylate (Crossgrove \& Zheng, 2004). The occurrence of Mn deficiency is rare though Mn toxicity has been known to affect the central nervous system (Sawka, 2005).

A diet with $\mathrm{Na} / \mathrm{K}$ ratio $<1$ is recommended and considered a good diet for reducing non-communicable diseases such as cardiovascular disease, stroke and hypertension (WHO, 2012; Oulai et al., 2014). The result showed that the P. umbellatum possesses a $\mathrm{Na} / \mathrm{K}$ ratio of $0.01<1$, thus the consumption of this plant is considered healthy. Prior studies conducted on various leafy vegetables also obtained a $\mathrm{Na} / \mathrm{K}$ ratio which was $<$ l (Hassan \& Umar, 2006; Ng et al., 2012; Srianta et al., 2015). The effect of these two elements in combination for combating high blood pressure and hypertension are larger than the effect of $\mathrm{K}$ or Na alone (Sacks et al., 2001; Perez \& Chang, 2014). The consumption of vegetables to lower cardiovascular disease risk have been reported by other researchers, thus P. umbellatum and other vegetables should be included a healthy 
daily diet (Mellendick et al., 2018). A Ca/P ratio which is $>1$ is recommended in a healthy diet whereas values $<0.5$ are considered to be insufficient (Adeyeye \& Aye, 2005). The $\mathrm{Ca} / \mathrm{P}$ ratio obtained in the study was $2.00>1$, thus the consumption of this plant can be considered as a healthy diet. Prior studies on various leafy vegetables also obtained similar results in terms of the $\mathrm{Ca} / \mathrm{P}$ ratio at $>1$ (Gupta et al., 2005; Ndlovu \& Afolayan, 2008; Oulai et al., 2014). Both $\mathrm{Ca}$ and $\mathrm{P}$ interact to form calcium phosphate which is required for the formation of hydroxylapatite, a mineral compound in bone osseous tissue (Lee et al., 2014).

\section{Antioxidants}

The presence of plant secondary metabolites potential antioxidants has attracted much attention due to the ability of antioxidants to defend against oxidative stress from free radical activity (Hossain \& Shah, 2015). Plant based foods especially vegetables have been touted as natural antioxidant as they tend to naturally contain high levels of phenolic compounds, flavonoids and ascorbic acid (Cartea et al., 2011; Hossain \& Shah, 2015). The contents of phenolic (TPC), flavonoids (TFC) and vitamin $\mathrm{C}$ obtained in the present study are presented in following order: TPC $>$ TFC $>$ vitamin $\mathrm{C}$ (Table 5).

The TPC content in P. umbellatum was found to be at concentrations of $510.63 \mathrm{mg}$ GAE/ $100 \mathrm{~g}$ which is about two times higher than Gnetum gnemon (253.45 mg GAE/100g) (Kongkachuichai et al., 2015). P. umbellatum contains a high concentration of TPC which shows its potential as a medicinal plant. The application of P. umbellatum as a medicinal plant has been reported in many previous studies (Roersch, 2010, Núñez et al., 2005). The phenolic compounds have the ability to act as an anti-carcinogenic compound by protecting body cells against oxidative damage (Silva et al., 2007).

P. umbellatum is also rich in flavonoids with a concentration of $377.82 \mathrm{mg} \mathrm{QE} / 100 \mathrm{~g}$. The results were comparable to Mussaendra afzelli $(367.00 \mathrm{mg} \mathrm{QE} / 100 \mathrm{~g})$ and Artemisia arboresense (325.00 mg QE/100g) (Agbo et al., 2015; Djeridane et al., 2006). Flavonoids are the largest subgroup of polyphenols are important as anti-cancer, anti-coronary heart diseases, anti-Alzheimer's disease and anti-cardiovascular diseases (Jang et al., 2018; Bakhtiari et al., 2017; Raffa et al., 2017). Vitamin $\mathrm{C}$ which is also a strong antioxidant was recorded to be present abundantly in leafy vegetables. P. umbellatum was found to have a concentration of $140.40 \mathrm{mg} / 100 \mathrm{~g}$ of vitamin $\mathrm{C}$ which is about 5- 16 times richer than various leafy vegetables as reported by Saha et al. (2015). P. umbellatum provides a good source of vitamin $\mathrm{C}$ which has the potential to reduce the risk of chronic diseases such as cancer (Kongkachuichai et al., 2015). Older people tend to consume leafy vegetables as a component of their daily diet due to the purported anti aging properties of food with high Vitamin C content (Samy et al., 2014).

\section{Anti-nutrient content}

Oxalate and phytate are the anti-nutritional factors which are commonly found in plant based foods. The result from this
Table 5. The phenolic, flavonoids and vitamin C content of P. umbellatum.

\begin{tabular}{lc}
\hline Parameter & Concentration \\
\hline TPC (mg GAE/l00g) & $510.63 \pm 10.12$ \\
TFC (mg QE/l00g) & $377.82 \pm 22.04$ \\
Vitamin C (mg/lo0g) & $140.40 \pm 2.80$ \\
\hline
\end{tabular}

Data presented as mean $\pm \mathrm{S} . \mathrm{E}$

Table 6. The nutrient and antinutrient composition of P. umbellatum.

\begin{tabular}{lc}
\hline Antinutrient $(\mathrm{mg} / \mathrm{l00g})$ & Concentration $(\mathrm{mg} / \mathrm{l00} \mathrm{g})$ \\
\hline Oxalate & $3.52 \pm 0.54$ \\
Phytate & $411.67 \pm 4.84$ \\
\hline
\end{tabular}

Data represented in means \pm standard error (SE) of the dry weight.

study shows that the phytic acid contained in P. umbellatum was comparatively higher than the oxalate content. The oxalate content was found to be in concentrations of $3.52 \mathrm{mg} / 100 \mathrm{~g}$ (Table 6). This was within the range recorded for other leafy vegetables consumed in India $(1.72-9.42 \mathrm{mg} / \mathrm{l00g}$ ) (Saha et al., 2015). Oxalate potentially binds to minerals such as K, $\mathrm{Ca}, \mathrm{Mg}$ and $\mathrm{Na}$, thus limiting the availability of these nutrients for body intake. The overconsumption of oxalate can cause the formation of calcium oxalate salt crystals which can precipitate in the kidney or urinary tract (Gemede \& Ratta, 2014).

Phytate in P. umbellatum was present in high concentrations; the content was recorded at $411.67 \mathrm{mg} / 100 \mathrm{~g}$. The results obtained fell within the range recorded in other various leafy vegetables $(103.16-924.70 \mathrm{mg} / 100 \mathrm{~g})$ as conducted by Saha et al. (2015). Phytic acid has a tendency to chelate to metal ions such as $\mathrm{Ca}, \mathrm{Mg}, \mathrm{Zn}, \mathrm{Cu}$ and Fe to form insoluble complexes which are not readily available for body absorption, thus limiting the accessibility to these nutrients (Gemede \& Ratta, 2014).

\section{CONCLUSIONS}

The consumption of $P$. umbellatum as a leafy vegetable can provide essential nutrients for body intake which is beneficial for consumers of this plant. The plant exhibits a high phytate content which could possibly reduce the availability of other nutrients. Soaking and boiling prior to consumption are the best methods suggested to reduce the anti-nutrient contents found in this plant. Taking into consideration the general nutritional value of this plant, it has suitable potential to be commercialized and introduced as a food crop. Thus, it is recommended that future studies be conducted to ascertain it's agronomical requirements.

\section{ACKNOWLEDGEMENT}

The authors wish to acknowledge the Faculty of Agriculture Science and Forestry, Universiti Putra Malaysia Sarawak Bintulu Campus for the technical support and facilities provided and Universiti Putra Malaysia for the research grant (GP/ IPM/2016/9493400), which made this study possible. 


\section{REFERENCES}

Abuye, C., Urga, K., Knapp, H., Selmar, D., Omwega, A. M., Imungi, J. K., \& Winterhalter, P. (2003). A compositional study of Moringa stenopetala leaves. East African Medical Journal, 80(5), 247-252. https://doi. org/10.4314/eamj.v80i5.8695

Adeyeye, E. \& Aye, P. A. (2005). Chemical composition and the effect of salts on the food properties of Triticum durum wholemeal flour. Pakistan Journal of Nutrition, 4(3), 187-196.

Agbo, M. O., Uzor, P. F., Akazie-Nneji, U. N., Eze-Odurukwe, C. U., Ogbatue, U. B., \& Mbaoji, C. (2015). Antioxidant, total phenolic and flavonoid content of selected Nigerian medicinal plants. Journal of Pharmaceutical Sciences, 14(1), 1-7.

Agbor, G. A., Vinson, J. A., Sortino, J., \& Johnson, R. (2012). Antioxidant and anti-atherogenic activities of three Piper species on atherogenic diet fed hamsters. Experimental and Toxicologic Pathology, 64(4), 387-391. https://doi.org/10.1016/i.etp.2010.10.003

Ainul Asyira, S., Noorasmah, S., Sarbini, S. R., \& Muta Harah, Z. (2016). Mineral content of five indigenous leafy vegetables from Bintulu Market, Sarawak Malaysia. Journal of Medicinal Herbs and Ethnomedicine, 2, 26-35. https://doi.org/10.19071/jmhe.2016.v2.3117

Alam, M. K., Rana, Z. H., \& Islam, S. N. (2016). Comparison of the proximate composition, total carotenoids and total polyphenol content of nine orange-fleshed sweet potato varieties grown in Bangladesh. Foods, 5(3), 64. https://doi.org/10.3390/foods5030064

AOAC. (1990). Official Methods of Analysis. $11^{\text {th }}$ ed. Washington, DC: Association of Official Analytical Chemists.

Asaolu, S. S., Adefemi, O. S., Oyakilome, I. G., Ajibulu, K. E., \& Asaolu, F. (2012). Proximate and mineral composition of nigerian leafy vegetables. Journal of Food Research, 1(3), 214-218.

Bakhtiari, M. Panahi, Y. Ameli, J., \& Darvishi, B. (2017). Protective effects of flavonoids against Alzheimer's disease-related neural dysfunctions. Biomedicine \& Pharmacotherapy, 93, 218-229. https:// doi.org/10.1016/j.biopha.2017.06.010

Barbagallo, M., Dominguez, L. J., Galioto, A., Ferlisi, A., Cani, C., Malfa, L., Pineo, A., Busardo', A., \& Paolisso, G. (2003). Role of magnesium in insulin action, diabetes and cardio-metabolic syndrome X. Molecular Aspects of Medicine, 24(1-3), 39-52. https://doi.org/10.1016/s00982997(02)00090-0

Brewer G. J. (2007). Iron and copper toxicity in diseases of aging, particularly atherosclerosis and Alzheimer's disease. Experimental Biology and Medicine, 232(2), 323-335.

Cartea, M. E., Francisco, M., Soengas, P., \& Velasco, P. (2010). Phenolic compounds in Brassica vegetables. Molecules, 16(1), 251-280. https://doi.org/10.3390/molecules16010251

Chasapis, C. T., Loutsidou, A. C., Spiliopoulou, C. A., \& Stefanidou, M. E. (2012). Zinc and human health: an update. Archives of Toxicology, 86(4), 521-534. https://doi.org/10.1007/s00204-011-0775-1

Crossgrove, J., \& Zheng, W. (2004). Manganese toxicity upon overexposure. NMR in Biomedicine, 17(8), 544-553. https://doi. org/10.1002/nbm.931

da Silva, I. F., Jr, de Oliveira, R. G., Mendes Soares, I., da Costa Alvim, T., Donizeti Ascêncio, S., \& de Oliveira Martins, D. T. (2014). Evaluation of acute toxicity, antibacterial activity, and mode of action of the hydroethanolic extract of Piper umbellatum L. Journal of Ethnopharmacology, 151(1), 137-143. https://doi.org/10.1016/j. jep.2013.10.011

Day, R. A., \& Underwood, A. L. (1986). Quantitative analysis. $5^{\text {th }}$ ed. United State: Prentice- Hall Publication.

Dewell, A. \& Ornish, D. (2007). Plant-based dietary patterns in the control of obesity and cardiovascular risk. Current Cardiovascular Risk Reports, 1, 9-15.

Djeridane, A., Yousfi, M., Nadjemi, B., Boutassouna, D., Stocker, P. \& Vidal, N. (2006). Antioxidant activity of some Algerian medicinal plants extracts containing phenolic compounds. Food Chemistry, 97(4), 654660. https://doi.org/10.1016/j.foodchem.2005.04.028

Eludoyin, O. M., \& Adelekan, I. O. (2013). The physiologic climate of Nigeria. International Journal of Biometeorology, 57(2), 241-264. https://doi.org/10.1007/s00484-012-0549-3

Gemede, H. F., \& Retta, N. (2014). Antinutritional factors in plant foods: potential health benefits and adverse effects. International Journal of Food Sciences and Nutrition, 3(4), 284-289.

Gupta, S., Lakshmi, J. A. A., Manjunath, M. N., \& Prakash, J. (2005). Analysis of nutrient and antinutrient content of under utilized green leaf vegetables. Food Science and Technology, 38(4), 339-345. https:// doi.org/10.1016/j.Iwt.2004.06.012

Hassan, L. G., \& Umar, K. J. (2006). Nutritional value of balsam apple (Momordica balsamina L.) leaves. Pakistan Journal of Nutrition, 5(6), 522-529.

He, K., Liu, K., Daviglus, M. L., Morris, S. J., Loria, C. M., Van Horn, L., Jacobs, D. R., Jr, \& Savage, P. J. (2006). Magnesium intake and incidence of metabolic syndrome among young adults. Circulation, 113(13), 1675-1682. https://doi.org/10.1161/CIRCULATIONAHA.105.588327

Heaney, R. P. (2004). Phosphorus nutrition and the treatment of osteoporosis. In: Mayo Clinic Proceedings.

Hoe, V. B., \& Siong, K. H. (1999). The nutritional value of indigenous fruits and vegetables in Sarawak. Asia Pacific Journal of Clinical Nutrition, 8(1), 24-31. https://doi.org/10.1046/j.1440-6047.1999.00046.x

Hossain, M. A., \& Shah, M. D. (2015). A study on the total phenols content and antioxidant activity of essential oil and different solvent extracts of endemic plant Merremia borneensis. Arabian Journal Chemistry, 89(1), 66-71. https://doi.org/10.1016/j.arabjc.2011.01.007

Iabal, M.J., Hanif, S., Mahmood, Z., Anwar, F. \& Jamil, A. 2012. Antioxidant and antimicrobial activities of Chowlai (Amaranthus viridis $L$.) leaf and seed extracts. Journal of Medicinal Plants Research, 6(27):4450-4455. https://doi.org/10.5897/JMPR12.822

Iwamoto, L. H., Vendramini-Costa, D. B., Monteiro, P. A., Ruiz, A. L., Sousa, I. M., Foglio, M. A., de Carvalho, J. E., \& Rodrigues, R. A. (2015). Anticancer and anti-inflammatory activities of a standardized dichloromethane extract from Piper umbellatum L. leaves. Evidencebased Complementary and Alternative Medicine, 2015, 948737 https://doi.org/10.1155/2015/948737

Jang, G. H., Kim, H. W., Lee, M. K., Jeong, S. Y., Bak, A. R., Lee, D. J., \& Kim, J. B. (2018). Characterization and quantification of flavonoid glycosides in the Prunus genus by UPLC-DAD-QTOF/MS. Saudi Journal of Biological Sciences, 25(8), 1622-1631. https://doi. org/10.1016/j.sjbs.2016.08.001

Kamtekar, S., Keer, V., \& Patil, V. (2014). Estimation of phenolic content, flavonoid content, antioxidant and alpha amylase inhibitory activity of marketed polyherbal formulation. Journal of Applied Pharmaceutical Science, 4(9), 61-65

Karp, H. J., Vaihia, K. P., Kärkkäinen, M. U., Niemistö, M. J., \& LambergAllardt, C. J. (2007). Acute effects of different phosphorus sources on calcium and bone metabolism in young women: a whole-foods approach. Calcified Tissue International, 80(4), 251-258. https://doi. org/10.1007/s00223-007-9011-7

Kenzo, T., Yoneda, R., Azani, M. A., \& Majid, N. M. (2008). Changes in leaf water use after removal of leaf lower surface hairs on Mallotus macrostachyus (Euphorbiaceae) in a tropical secondary forest in Malaysia. Journal of Forester Research, 13, 137-142. https://doi. org/10.1007/s10310-008-0062-z

Kongkachuichai, R., Charoensiri, R., Yakoh, K., Kringkasemsee, A., \& Insung, P. (2015). Nutrients value and antioxidant content of indigenous vegetables from Southern Thailand. Food Chemistry, 173, 838-846. https://doi.org/10.1016/j.foodchem.2014.10.123

Lee, K. J., Kim, K. S., Kim, H. N., Seo, J. A., \& Song, S. W. (2014). Association between dietary calcium and phosphorus intakes, dietary calcium/ phosphorus ratio and bone mass in the Korean population. Nutrition Journal, 13(1), 114. https://doi.org/10.1186/1475-2891-13-114

Lucas, G. M. and Markakas, P. (1975). Phytic acid and other phosphorus compounds of beans (Phaseolus vulgaris L.). Journal of Agricultural and Food Chemistry, 23(1), 13-15. https://doi.org/10.1021/ jf60197a016

Madeiros, L., \& Boligon, D. S. (2007). Adaptations of two specialist herbivores to movement on the hairy leafsurface of their host, Solanum guaraniticum Hassl (Solanacea). Revista Brasileira de Entomologia, 51(2), 210-216. https://doi.org/10.1590/S008556262007000200011

Mellendick, K., Shanahan, L., Wideman, L., Calkins, S., Keane, S., \& Lovelady, C. (2018). Diets rich in fruits and vegetables are associated with lower cardiovascular disease risk in adolescents. Nutrients, 10(2), 136. https://doi.org/10.3390/nu10020136

Mensah, J. K., Okoli, R. I., Ohaju-Obodo, J. O., \& Eifediyi, K. (2008). Phytochemical, nutri-cional and medicinal properties of some leafy vegetables consumed by Edopeople of Nigeria. African Journal of Biotechnology, 7, 2304-2309.

Mensah, J., Ihenyen, J. \& Okhiure, M. O. (2013). Nutritional, phytochemical, and antimicrobial properties of two wild aromatic vegetables from 
Edo State. Journal of Natural Product and Plant Resources, 3(1), 8-14.

Murphy, J., \& Riley, J. P. (1962). Modified single solution method for the determination of phosphate in natural waters. Analytica Chimica Acta, 27, 31-36. https://doi.org/10.1016/S0003-2670(00)88444-5

Ndlovu, J., \& Afolayan, A. J. (2008). Nutritional analysis of the South African wild vegetable Corchorus olitorius L. Asian Journal of Plant Sciences, 7(6), 615-618. https://doi.org/10.3923/ajps.2008.615.618

Ng, X. N., Chye, F. Y., \& Ismail, A. M. (2012). Nutritional profile and antioxidant properties of selected tropical vegetables. International Food Research Journal, 19, 1487-96.

Núñez, V., Castro, V., Murillo, R., Ponce-Soto, L. A., Merfort, I., \& Lomonte, B. (2005). Inhibitory effects of Piper umbellatum and Piper peltatum extracts towards myotoxic phospholipases A2 from Bothrops snake venoms: isolation of 4-nerolidylcatechol as active principle. Phytochemistry, 66(9), 1017-1025. https://doi.org/10.1016/j. phytochem.2005.03.026

Nwauzoma, A. B., \& Dawari, S. L. (2013). Study on the phytochemical properties and proximate analysis of Piper umbellatum L. from Nigeria. American Journal of Research Communication, 1(7), 164-177.

Odhav, B., Beekrum, S., Akula, U. S., \& Baijnath, H. (2007). Preliminary assessment of nutritional value of traditional leafy vegetables in KwaZulu-Natal, South Africa. Journal of Food Composition and Analysis, 20(5), 430-435. https://doi.org/10.1016/j.jfca.2006.04.015

Ooi, D. J., Iqbal, S., \& Ismail, M. (2012). Proximate composition, nutritional attributes and mineral composition of Peperomia pellucida L. (Ketumpangan Air) grown in Malaysia. Molecules, 17(9), 1113911145. https://doi.org/10.3390/molecules170911139

Otten, J. J., Hellwig, J. P., \& Meyers, L. D. (2006). Dietary reference intakes: the essential guide to nutrient requirements. The National Academic Press: Washington DC.

Oulai, P., Zoue, L., Megnanou, R. M., Doue, R., \& Niamke, S. (2014). Proximate composition and nutritive value of leafy vegetables consumed in Northern Côte D'ivoire. European Science Journal, 10, 212-27.

Parthasarathy, U., Saji, K. V., Jayarajan, K., \& Parthasarathy, V. A. (2006). Biodiversity of Piper in South India - application of GIS and cluster analysis. Current Science, 91(5), 652-658.

Perez, V., \& Chang, E. T. (2014). Sodium-to-potassium ratio and blood pressure, hypertension, and related factors. Advances in Nutrition, 5(6), 712-741. https://doi.org/10.3945/an.114.006783

Pohle, P., \& Reinhardt, S., (2004). Indigenous knowledge of plants and their utilization among the Shuar of the lower tropical mountain forest in southern Ecuador. Lyonia, 7,133-149.

Prajapati, K., \& Modi, H. A. (2012). The importance of potassium in plant growth- a review. Indian Journal of Plant Sciences, 1(2), 177-186.

Raffa, D., Maggio, B., Raimondi, M. V., Plescia, F., \& Daidone, G. (2017). Recent discoveries of anticancer flavonoids. European Journal of Medicinal Chemistry, 142, 213-228. https://doi.org/10.1016/j. ejmech.2017.07.034

Roersch C. M. (2010). Piper umbellatum L.: a comparative crosscultural analysis of its medicinal uses and an ethnopharmacological evaluation. Journal of Ethnopharmacology, 131(3), 522-537. https:// doi.org/10.1016/j.jep.2010.07.045

Rukayah, A. (2002). Ulam dan sayuran tempatan Semenanjung Malaysia. $2^{\text {nd }}$ ed. Dewan Bahasa dan Pustaka. Kuala Lumpur.

Sacks, F. M., Svetkey, L. P., Vollmer, W. M., Appel, L. J., Bray, G. A., Harsha, D., Obarzanek, E., Conlin, P. R., Miller, E. R., SimonsMorton, D. G., Karanja, N., Lin, P. H., \& DASH-Sodium Collaborative Research Group (2001). Effects on blood pressure of reduced dietary sodium and the Dietary Approaches to Stop Hypertension (DASH) diet. DASH-Sodium Collaborative Research Group. The New England Journal of Medicine, 344(1), 3-10. https://doi.org/10.1056/ NEJM200101043440101

Saha, J., Biswal, A. K., \& Deka, S. C. (2015). Chemical composition of some underutilized green leafy vegetables of Sonitpur district of Assam, India. International Food Research Journal, 22(4), 1466-1473.

Samy, J., Sugumaran, M., \& Lee, K. L. (2014). Historical background. In K. M. Wong, (Eds.), 100 Useful Herbs of Malaysia and Singapore: An Introduction to their Medicinal, Culinary, Aromatic and Cosmetic Uses. Singapore: Marshall Carvendish Editions.

Saupi, N., Zakaria, M. \& Bujang, J. S. (2009). Analytic chemical composition and mineral content of yellow velvetleaf (Limnocharis flava L. Buchenau)'s edible parts. Journal of Applied Sciences, 9(160), 29692974. https://doi.org/10.3923/jas.2009.2969.2974

Sawka, M. N. (2005). Dietary reference intakes for water, potassium, sodium chloride, and sulphate. Chapter 4-Water. DTIC.

Silva, E. M., Souza, J. N. S., Rogez, H., Rees, J. F., \& Larondelle, Y. (2007). Antioxidant activities and polyphenolic contents of fifteen selected plant species from the Amazonian region. Food Chemistry, 101(3), 1012-1018. https://doi.org/10.1016/.j.foodchem.2006.02.055

Singleton, V. L., Orthofer, R., \& Raventos, L. (1999). Analysis of total phenols and other oxidation substrates and antioxidants by means of folinciocalteu reagent. Methods in Enzymology, 299, 152-178. https://doi. org/10.1016/S0076-6879(99)99017-1

Soetan, K. O, Olaiya C. O., \& Oyewole, O. E. (2009). The importance of mineral elements for humans, domestic animals and plants: A review. African Journal of Food Science, 4(5), 200-222.

Song, Y., Manson, J. E., Buring, J. E., \& Liu, S. (2004). Dietary magnesium intake in relation to plasma insulin levels and risk of type 2 diabetes in women. Diabetes Care, 27, 59-65.

Srianta, I., Patria, H. D., Arisasmita, J. H., \& Epriliati, I. (2012). Ethnobotany, nutritional composition, and DPPH radical scavenging of leafy vegetables of wild Paederia foetida and Erechtites hieracifolia. International Food Research Journal, 19(1), 245-250.

Tawan, C. S., Ipor, I. B., Fashihuddin, B. A., \& Hamsawi, S. (2002). A brief account on the wild Piper (Piperaceae) of the Crocker Range, Sabah. ASEAN Review of Biodiversity and Environmental Conservation (ARBEC).

Wang, M., Zheng, Q., Shen, Q., \& Guo, S. (2013). The critical role of potassium in plant stress response. International Journal of Molecular Sciences, 14(4), 7370-7390. https://doi.org/10.3390/ijms14047370

Weaver, C. M. (2013). Potassium and health. Advance Nutrition International Review Journal, 4, 3685-775.

World Health Organization (2012). Guideline: potassium intake for adults and children. World Health Organization.

Yisa, J., Egila, J. N., \& Darlinton, A.O. (2010). Chemical composition of Annona senegalensis from Nupe land, Nigeria. African Journal of Biotechnology, 9(26), 4106-4109. 